\title{
Faktor-Faktor yang Mempengaruhi Tingkat Pengangguran di Provinsi Kalimantan Timur
}

\author{
Aboy Kurniawan ${ }^{1}$, Adnan Haris Musa ${ }^{2}$, Rachmad Budi Suharto ${ }^{3}$ \\ Fakultas Ekonomi dan Bisnis Universitas Mulawarman, Samarinda \\ ${ }^{1}$ Email: aboy.kurniawan@mhs.feb.unmul.ac.id \\ ${ }^{2}$ Email: adnan.haris.musa@feb.unmul.ac.id \\ ${ }^{3}$ Email:_rachmad.budi.suharto@feb.unmul.ac.id
}

\begin{abstract}
Abstrak
Tujuan dari penelitian ini adalah untuk mengetahui pengaruh populasi, inflasi dan investasi pada tingkat pengangguran terbuka di Provinsi Kalimantan Timur. Metode atau alat analisis yang digunakan dalam penelitian ini adalah pendekatan analisis regresi berganda terhadap asumsi klasik yang diproses secara terperinci. Penelitian ini menggunakan data sekunder yang diperoleh dari Badan Pusat Statistik (BPS). Dari hasil analisis data yang saya lakukan dapat disimpulkan bahwa: (1) Populasi besar dapat menggerakkan pasar dalam hal permintaan melalui multiplier effect karena permintaan agregat tinggi. (2) Dari hasil pengamatan diketahui bahwa ada hubungan yang erat antara inflasi dan pengangguran. (3) Ukuran investasi yang terjadi di masyarakat akan sangat mempengaruhi ukuran lapangan kerja yang tercipta.
\end{abstract}

Kata Kunci: Analisis Regresi; Populasi; Inflasi; Investasi; Pengangguran

\section{Factors Affecting Unemployment Rate in East Kalimantan Province}

\begin{abstract}
The purpose of this study was to determine the effect of population, inflation and investments in open unemployment in the province of East Kalimantan. The method or tool of analysis used in this research is multiple regression analysis approach to the classical assumptions are processed in a detailed explanation. This study uses secondary data obtained from the Central Statistics Agency (BPS). From the results of data analysis that I do can be concluded that: (1) Large population can move the market in terms of demand through the multiplier effect due to the aggregate demand is high. (2) From the results it is observed that there is a close relationship between inflation and unemployment. (3) The size of investments that occurred in the community will greatly affect the size of employment opportunities created.
\end{abstract}

Keywords: Regression Analysis; Population; Inflation; Investment; Unemployment 


\section{PENDAHULUAN}

Pertumbuhan ekonomi merupakan salah satu indikator dalam menilai kinerja perekonomian. Ekonomi mengalami pertumbuhan apabila produksi barang serta jasa selalu meningkat setiap tahunnya. Pertumbuhan ekonomi menunjukan sejauh mana aktivitas perekonomian dapat menghasilkan tambahan pendapatan atau kesejahteraan masyarakat pada priode tertentu ( Alghofari, 2010 ).

Indonesia sebagai negara berkembang dengan jumlah penduduk terbesar keempat didunia memiliki potensi pasar yang cukup besar dilihat dari sisi input tenaga kerja. Jumlah penduduk yang besar dapat menggerakkan pasar dari sudut permintaan melalui multiplier effect karena adanya aggregat demand yang tinggi. Namun pada kenyataannya jumlah penduduk dan tenaga kerja yang besar di Indonesia belum dapat menjadi asset potensial yang dapat dikembangan dan mendorong kegiatan ekonomi. Hal ini didukung oleh pendapat beberapa para ahli yang menyatakan bahwa pertumbuhan jumlah penduduk yang cepat dapat menghambat pertumbuhan ekonomi (Riswandi, 2011).

Kalimantan timur merupakan salah satu provinsi yang ada di Indonesia dengan jumlah pengangguran terbesar pada tahun 2012 saja tingkat pengangguran di Kalimantan Timur sebesar 9,02 persen dari jumlah penduduk yang mencapai 3.508 juta orang. Kalimantan Timur memiliki 8 kabupaten/kota diantaranya adalah kaupaten Paser, Kutai Barat, Kutai Kartanegara, Kutai Timur, Peneajam Paser Utara, Balikpapan, Samarinda, dan Bontang. Berikut adalah jumlah pengangguran di Kalimantan Timur sejak tahun 2003 - 2012 (BPS Kalimantan Timur).

Tabel 1. Jumlah Tingkat Pengangguran di Kalimantan Timur 2003 - 2012

\begin{tabular}{ccc}
\hline No & Tahun & Jumlah Tingkat Pengangguran (\%) \\
\hline 1 & 2003 & 9.69 \\
2 & 2004 & 10.39 \\
3 & 2005 & 9.04 \\
4 & 2006 & 13.34 \\
5 & 2007 & 12.07 \\
6 & 2008 & 11.11 \\
7 & 2009 & 10.83 \\
8 & 2010 & 10.10 \\
9 & 2011 & 9.84 \\
10 & 2012 & 9.02 \\
\hline
\end{tabular}

Sumber: BPS Provinsi KalimantanTimur

Dari tabel diatas dapat kita lihat jumlah pengangguran di Kalimantan Timur pada tahun 20032012, pada priode tersebut saja kita dapat lihat bahwa angka pengangguran di Kalimantan Timur melonjak dan menurun, ini bukan merupakan perkembangan yang baik untuk mengatasi angka pengangguran di Kalimantan Timur, seharusnya pemerintah dengan program-program yang telah di rancang dapat menekan angka pengangguran dari tahun ketahunnya, dalam kurun waktu 10 tahun berdasarkan data di atas dapat kita lihat angka pengangguran terbesar terjadi di tahun 2006, terhitung sejak tahun 2006 menuju 2012 angka pengangguran di Kalimantan Timur mengalami penurunan yang pada tahun 2006 berada pada 13.34 di tahun 2012 menjadi 9.02 .

Dari latar belakang yang telah disampaikan di atas penulis ingin meneliti Faktor-faktor yang mempengaruhi tingkat pengangguran di provinsi Kalimantan Timur. karena melihat angka pengangguran di provinsi Kalimantan Timur yang setiap tahunnya mengalami peningkatan dan sumber daya alam yang dimiliki oleh provinsi Kalimantan Timur yang cukup besar.

\section{Ketenagakerjaan}

Sumber daya manusia mengandung dua pengertian. Pertama, sumber daya manusia mengandung pengertian usaha kerja yang diberikan dalam proses produksi. Dalam hal ini sumber daya manusia mencerminkan kualitas usaha yang diberikan seseorang dalam waktu tertentu untuk menghasilkan barang atau jasa. 


\section{Pertumbuhan Penduduk}

Penduduk adalah semua orang yang berdomisili di wilayah geografis Indonesia selama enam bulan atau lebih dan atau mereka yang berdomisili kurang dari enam bulan tetapi bertujuan menetap. Pertumbuhan penduduk diakibatkan oleh tiga komponen yaitu: fertilitas, mortalitas dan migrasi.

\section{Fertilitas}

Fertilitas sebagai istilah demografi diartikan sebagai hasil reproduksi yang nyata dari seorang wanita atau sekelompok wanita. Dengan kata lain fertilitas ini menyangkut banyaknya bayi yang lahir hidup.

\section{Migrasi}

Migrasi adalah perpindahan penduduk dengan tujuan untuk menetap dari suatu tempat ke tempat lain melampaui batas politik/negara atau pun batas administratif/batas bagian dalam suatu negara. Jadi migrasi sering diartikan sebagai perpindahan yang relatif permanen dari suatu daerah ke daerah lain.

\section{Investasi}

Investasi, yang lazim disebut juga dengan istilah penanaman modal atau pembentukan modal merupakan komponen kedua yang menentukan tingkat pengeluaran agregat.

\section{Hubungan Antar Variabel}

Menurut Todaro (2003:404-406) yang mempengaruhi produktivitas adalah modal manusia yang meliputi pendidikan dan kesehatan. Keduanya adalah hal fundamental untuk membentuk kapabilitas manusia yang lebih luas yang berada pada inti makna pembangunan (Zulhanafi, dkk, 2013).

\section{Rincian Data Yang Diperlukan}

Data yang diperlukan dalam penelitian adalah sebagai berikut:

1. Data Pertumbuhan Penduduk Kalimantan Timur dari tahun 2005 - 2014

2. Data inflasi Provinsi Kalimantan Timur dari tahun 2005 - 2014

3. Data investasi Provinsi Kalimantan Timur dari tahun 2005 - 2014

4. Data jumlah pengangguran Provinsi Kalimantan Timur dari tahun $2005-2014$

\section{Metode Pengumpulan Data}

Sistem pengumpulan data yang digunakan adalah melalui Library Research yaitu pengumpulan data hasil penelitian instansi terkait atau penulisan yang dimuat dalam bentuk laporan, literatur, majalah dan tulisan ilmiah yang berkaitan langsung dengan materi penelitian dan data yang dikumpulkan adalah data sekunder.

\section{Metode Analisis}

Metode analisis yang digunakan dalam penelitian ini adalah fungsi Cobb Douglas dimana fungsi ini dipergunakan untuk menganalisis data yang non linear. Untuk mengukur pengaruh pertumbuhan penduduk, inflasi dan investasi terhadap pengangguran digunakan fungsi Cobb Douglas, dengan persamaan sebagai berikut:

$$
\mathrm{Q}=\llbracket \mathrm{AK} \rrbracket \wedge^{\wedge} \mathrm{L}^{\wedge} \mathrm{b} \ldots{ }^{\wedge} \mathrm{x}
$$

Sesuai dengan penelitian ini fungsi tersebut menjadi :

Dimana :

$$
\mathrm{U}=\mathrm{A} \mathrm{Pb} 1 \mathrm{Ib} 2 \mathrm{Mb} 3
$$

$$
\begin{gathered}
\mathrm{U}=\text { Tingkat Pengangguran } \\
\mathrm{P}=\text { Pertumbuhan penduduk } \\
\mathrm{I}=\text { Inflasi } \\
\mathrm{M}=\text { Investasi } \\
\text { A1b1b2 b3 = Bilangan Konstan }
\end{gathered}
$$


Besarnya A1b1b2 b3 dapat diperoleh dengan menggunakan fungsi statistik linier berganda dan melinierkan fungsi Cobb Douglas.

Dengan menggunakan Log sebagai berikut :

$\log \mathrm{U}=\log \mathrm{A} b 0+\log \mathrm{P} b 1+\log \mathrm{I} b 2+\log \mathrm{M} b 3$

Dimana :

$$
\begin{aligned}
& \log \mathrm{U}=\mathrm{y} \\
& \log \mathrm{A}=\mathrm{b} 0 \\
& \log \mathrm{P}=\mathrm{X} 1 \\
& \log \mathrm{I}=\mathrm{X} 2 \\
& \log \mathrm{M}=\mathrm{X} 3
\end{aligned}
$$

Maka :

$$
\mathrm{Y}=\mathrm{b} 0+\mathrm{b} 1 \mathrm{X} 1+\mathrm{b} 2 \mathrm{X} 2+\mathrm{b} 3 \mathrm{X} 3
$$

Untuk menghitung $\mathrm{b} 0, \mathrm{~b} 1$ dan $\mathrm{b} 2$ digunakan rumus sebagai berikut :

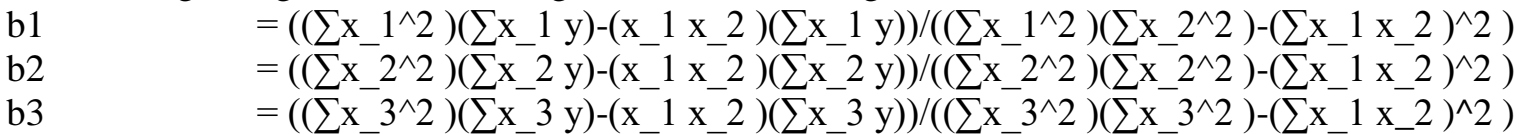

Selanjutnya untuk menguji pengaruh secara simultan uji $\mathrm{F}$ untuk parsial dengan uji $\mathrm{t}$.

$\mathrm{Fh}=\left(\mathrm{R}^{\wedge} 2 /(\mathrm{k}-1)\right) /\left(\left(\left(1-\mathrm{R}^{\wedge} 2\right)\right)((\mathrm{n}-\mathrm{k}))\right)$

Dimana :

$$
\begin{aligned}
& \mathrm{R} 2=\sqrt{ }\left(\left(\mathrm{b} \_1 \sum \mathrm{x} \_1 \mathrm{y}+\mathrm{b} \_2 \sum \mathrm{x} \_2 \mathrm{y}\right) /\left(\sum \mathrm{y}^{\wedge} 2\right)\right) \\
& \text { th }=\left(\mathrm{b} \_1-\beta \_1\right) /\left(\operatorname{Sb} \_1\right)
\end{aligned}
$$

Hipotesis menyatakan $\mathrm{X}$ berpengaruh signifikan terhadap Y.

Rumusan Hipotesis :

$\mathrm{H} 0: \beta \_1,2,3=0 ; \mathrm{H} 1: \beta \_1,2,3 \neq 0: \mathrm{H} 0$ diterima apabila $-\mathrm{t}$ tabel $\leq \mathrm{th} \leq$ thabel $; \mathrm{H} 0$ ditolak apabila th $>$ $\mathrm{t}$ tabel th $<$ ttabel

Proses selanjutnya adalah :

$\mathrm{H} 0: \beta=0 \quad$ berarti variable $\mathrm{x} 1$ dan $\mathrm{x} 2$ tidak ada hubungannya yang nyata dengan variabel $\mathrm{Y}$.

Ha $: \beta \neq 0 \quad$ berarti variable $\mathrm{x} 1$ dan $\mathrm{x} 2$ ada hubungan yang nyata dengan variabel $\mathrm{Y}$.

Asumsi Regresi

\section{Uji Normalitas}

Uji normalitas adalah pengujian asumsi residual yang berdistribusi normal. Asumsi ini harus terpenuhi untuk model regresi yang baik. Asumsi normalitas dapat diperiksa dengan pemeriksaan output normal $\mathrm{P}-\mathrm{P}$ plot atau normal $\mathrm{Q}-\mathrm{Q}$ plot. Asumsi normalitas terpenuhi jika pengujian normalitas menghasilkan $\mathrm{P}-$ value (Sign.) $>$ a dengan nilai a ditentukan sebesar 1\%, 5\%, atau $10 \%$.

\section{Uji Multikolinearitas}

Uji multikolinearitas merupakan pengujian untuk mengetahui ada atau tidaknya korelasi yang signifikan antara variabel - variabel independen dalam suatu model regresi linear berganda. Pada uji ini, diharapkan nilai VIF < 10 atau korelasi pearson antara variabel - variabel bebas signifikan $(\mathrm{P}$ - value (Sign.) $<a=5 \%$ atau 10\%) sehingga asumsi multikolinearitas tidak terpenuhi.

\section{Uji Heterokedastisitas}

Pengujian heterokedastisitas merupakan uji asumsi residual dengan varians tidak konstan. Deteksi heterokedastisitas dapat dilakukan dengan menampilkan scatter plot dari nilai ZPRED (nilai prediksi, sumbu X) dengan SRESID (nilai residual, sumbu Y).

\section{Uji Autokorelasi}

Uji autokorelasi merupakan pengujian asumsi residual yang memiliki korelasi pada periode ke $-\mathrm{t}$ dengan periode sebelumnya $(\mathrm{t}-1)$. Untuk menggunakan uji autokorelasi kita menggunakan uji Durbin - Watson (DW). Uji ini menghasilkan nilai DW hitung (d) dan nilai DW table (dL dan dV). Aturan pengujiannya adalah: 
Volume 19 (2), 2017
$\mathrm{d}<\mathrm{dL}$
: Terjadi masalah autokorelasi yang positif yang perlu perbaikan
$\mathrm{dL}<\mathrm{d}<\mathrm{dU} \quad$ : Ada masalah autokorelasi positif tetapi lemah
$\mathrm{dU}<\mathrm{d}<4-\mathrm{dU} \quad$ : Tidak ada masalah autokorelasi
4-dU $<\mathrm{d}<4-\mathrm{dL} \quad$ : Masalah autokorelasi lemah
4-dL $<\mathrm{d} \quad$ : Masalah autokorelasi serius

\section{HASIL PENELITIAN DAN PEMBAHASAN}

Tabel 2. Data hasil penelitian

\begin{tabular}{ccccc}
\hline Tahun & $\begin{array}{c}\text { Jumlah Penduduk } \\
(\boldsymbol{\%})\end{array}$ & Tingkat Inflasi (\%) & Investasi (Rp) & $\begin{array}{c}\text { Jumlah } \\
\text { Pengangguran } \\
(\text { Jiwa) }\end{array}$ \\
\hline 2005 & 4,97 & 6,83 & 9647225,81 & 12,43 \\
2006 & 2,37 & 6,60 & 10984735,98 & 12,17 \\
2007 & 2,34 & 5,06 & 12225515,33 & 12,07 \\
2008 & 2,31 & 5,30 & 12922673,04 & 11,11 \\
2009 & 2,27 & 4,31 & 14589159,29 & 10,83 \\
2010 & 3,82 & 5,28 & 16139985,59 & 10,10 \\
2011 & 3,86 & 6,35 & 29113584,60 & 9,84 \\
2012 & 3,27 & 5,60 & 30478370,00 & 8,90 \\
2013 & 2,37 & 9,65 & 33096712,70 & 7,94 \\
2014 & 2,24 & 7,44 & 37872764,88 & 7,54 \\
\hline
\end{tabular}

Sumber: Data diolah

Dari table hasil penelitian diatas terlihat bahwa pertumbuhan penduduk dan tingkat inflasi di Kalimantan Timur mengalami naik turun dari tahun 2005 sampai dengan 2014. Sedangkan investasi yang terdiri dari Penanaman Modal Dalam Negeri ( PMDN ) dan penanaman modal asing (PMA) di Kalimantan Timur setiap tahunnya dari tahun 2005 sampai dengan 2014 mengalami peningkatan. Di satu sisi tingkat pengangguran terbuka di Kalimantan Timur mengalami penurunan dari tahun 2005 hingga tahun 2014, walaupun tingkat penurunan tersebut cenderung pelan. Dari table hasil perolehan data hasil penelitian diatas, peneliti menemukan hal yang menarik, dimana dalam penelitian ini terdapat data - data yang bervariatif.

\section{Heterokedastisitas}

Dengan melihat sebaran titik - titik yang acak pada hasil pengolahan data pada penelitian ini, baik diatas maupun dibawah angka 0 dari sumbu Y, dapat disimpulkan pada penelitian ini tidak terjadi gejala heteroskedastisitas.

Pada tabel model summary diatas, terlihat nilai besaran koefisien korelasi yang ditunjukan dari nilai $\mathrm{R}$ sebesar 0,962 yang artinya pada penelitian ini varibel Pertumbuhan Penduduk, Inflasi, dan Investasi memiliki hubungan yang sangat kuat terhadap Pengangguran Terbuka.

Pada table diatas juga menunjukan nilai koefisien determinasi yang ditunjukan oleh nilai Adjusted $R$ Square yaitu sebesar 0,926 yang memberikan arti bahwa variable Pertumbuhan Penduduk, Inflasi, dan Investasi memberikan besaran peran atau kontribusi variable terhadap Pengangguran Terbuka sebesar $92,6 \%$, sedangkan sisanya $17,4 \%$ dipengaruhi variable lain diluar variable yang diambil pada penelitian ini.

\section{SIMPULAN}

Berdasarkan hasil olah data penelitian yang telah dianalisis pada bab sebelumnya maka dapat ditarik sebuah kesimpulan sebagai berikut :

1. Jumlah penduduk memiliki pengaruh positif, akan tetapi tidak signifikan terhadap tingkat pengangguran terbuka

2. Inflasi memiliki pengaruh negatif, akan tetapi tidak signifikan terhadap tingkat pengangguran terbuka 
3. Investasi memiliki pengaruh yang negatif dan signifikan terhadap tingkat pengangguran terbuka

4. Jumlah penduduk memiliki pengaruh yang dominan terhadap tingkat pengangguran terbuka.

\section{DAFTAR PUSTAKA}

Alghofari, Farid. 2010. Analisis Tingkat Pengangguran Di Indonesia. Fakultas Ekonomi Universitas Diponegoro Semarang.

Boediono, 1988. Ekonomi Makro. Yogyakarta: BPFE UGM.

Dominick, Salvatore. 1997. Ekonomi Internasional, alih bahasa oleh Haris Munandar edisi 5 cetak 1. Erlangga, Jakarta.

Imam Ghozali. 2006, Aplikasi Analisis Multivariat Dengan Program SPSS, Cetakan Keempat. Badan Penerbit Universitas Diponegoro, Semarang

Kaufman, Bruce E dan Julie L. Hotchkiss. 1999. The Economics of Labor Markets. Yogyakarta: BPFE UGM.

Nainggolan dkk. 2005. Teori Ekonomi Mikro. Edisi Pertama. Pondok Edukasi. Malang.

Payaman J. Simanjuntak. 1985. Pengantar Ekonomi Sumber Daya Manusia. Penerbit FEUI (Fakultas Ekonomi Universitas Indonesia), Jakarta.

Priyatno, Dwi, 2008. Mandiri Belajar SPSS untuk Analisis Data dan Uji Statistik, Edisi Pertama, Mediakom, Jakarta.

Salam Kadir Abdul, 2010. Jurnal Teori-teori Pembangunan Ekonomi, http:/www.abdulkadirsalam.com.

Samuelson, P.A., W.D. Nordhaus, 1986. Ekonomi, Edisi Keduabelas, Jilid I, Diterjemahkan oleh A. Jaka Wasana, Penerbit Erlangga.

Santosa Purbayu, 2005. Analisis Statistik Dengan Microsoft Excel dan SPSS. Penerbit Yogyakarta

Sukirno, Sadono. 1981. Pengantar Teori Makro Ekonomi. Bina Grafika. Jakarta.

Sukirno, Sadono. 1998. Pengantar Ekonomi Makro, PT. Raja Grafindo Persada. Jakarta.

Sukirno, Sadono. 1999. Pengantar Teori Makro Ekonomi. PT. Raja Grafindo Persada. Jakarta.

Sukirno, Sadono. 2006. Makroekonomi: Teori Pengantar, Penerbit PT. Raja Grafindo Persada, Jakarta.

Sukirno, Sadono. 2006. Ekonomi Pembangunan Proses Masalah dan Dasar Kebijakan. Jakarta: Penerbit Kencana.

Suparmoko, 1997, Ekonomi Sumber Daya Alam dan Lingkungan, BPFE, Yogyakarta.

Tambunan, Tulus T.H, 2009, UMKN di Indonesia, Ghalia Indonesia, Bogor.

Waluyo, Dwi Eko. 2007. Ekonomi Makro. Malang: UMM Press.

Zulhanafi, dkk. 2013. "Analisis Faktor-faktor Yang Mempengaruhi Produktivitas dan Tingkat Pengengguran Di Indonesia". Jurnal Kajian Ekonomi, 2 (3): 